\title{
PENGARUH COVID-19 TERHADAP KEHIDUPAN MASYARAKAT INDONESIA: SEKTOR PENDIDIKAN, EKONOMI DAN SPIRITUAL KEAGAMAAN
}

\author{
M. Wahyu Pratama Putra ${ }^{[1]}$, Kurnia Sari Kasmiarno ${ }^{[2]}$ \\ ${ }^{[1,2]}$ Mahasiswa Magister Agama dan Lintas Budaya Minat Ekonomi Islam, \\ Universitas Gadjah Mada
}

\begin{abstract}
ABSTRAK
Pandemi Covid-19 telah mampu mempengaruhi sendi-sendi kehidupan masyarakat luas, terutama di Indonesia. Mulai dari sektor pendidikan, perekonomian, hingga pada sektor spiritual umat beragama dalam menjalankan ibadah. Penelitian dilakukan secara kualitatif, dengan sumber dari literature dan diperkuat dengan wawancara terstrukur kepada beberapa pelaku yang bekerja pada sektor-sektor yang diangkat. Penelitian ini memaparkan kehidupan masyarakat terkait perubahan yang dirasa, dampak dan trauma yang dihadapi, bagaimana mereka survive serta hikmah yang dipetik dalam segala keterbatasan akibat pandemic. Hasil yang diperoleh pada penelitian ini yaitu pada sektor pendidikan terdapat sistem daring, dengan dampak yang kurang efektif. Sedangkan disektor ekonomi mengubah masyarakat lebih kreatif, namun tetap berdampak pada penurunan penghasilan. Disisi spiritual keagamaan membentuk kegiatan keagamaan beradaptasi dengan keadaan, yang berdampak pada kegiatan agama di rumah, secara live streaming, dll. Selain itu, trauma yang dialami berupa rasa takut tertular virus Covid. Namun, mereka tetap survive dengan belajar mandiri, menekan biaya pengeluran dan memperbanyak ibadah. Hikmah yang diperoleh atas pandemic ini yaitu lebih sering berkumpul dengan keluarga, semakin kreatif, khusyuk dalam beribadah dan terpupuknya jiwa saling membantu.
\end{abstract}

Kata Kunci: Covid-19, Pendidikan, Ekonomi, Spiritual Keagamaan

\section{ABSTRACT}

The Covid-19 has been able to affect the joints life in the wider community, especially in Indonesia. Starting from the education sector, the economy, to the spiritual sector of religious communities in 
carrying out worship. The research was conducted qualitatively with sources from literature and strengthened by structured interviews with several people who works in the sectors raised. This study describes people's live related to the changes they fell, the impacts and traumas they face, how they survive and the lessons learned in all the limitations caused by the pandemic. The results obtained in this study was that in the education sector there is an online system, with a less effect impact. Meanwhile, the economic sector changes society to be more creative, but it still has an impact on decreasing income. On the spiritual side, religion forms religious activities to adapt to circumstances, which have an impact on religious activities at home, live streaming, etc. In addition, the trauma experienced is in the form of fear of contracting the Covid virus. However, they still survive by studying independently, reducing costs and increasing worship. The wisdom gained from this pandemic is to gather more often with family, be more creative, be more devoted in worship and cultivate a spirit of mutual help.

Keywords: Covid-19, Education, Economics, Spiritual Religion

\section{A. PENDAHULUAN}

Diawal tahun 2020, dunia dikejutkan dengan hadirnya virus baru yang menyerang sistem pernapasan manusia yang dikenal dengan Corona Virus (Covid-19). Virus ini awalnya diketahui menyerang China tepatnya di kota Wuhan pada November 2019 silam. Covid-19 yang diprediksi hanya merupakan virus normal ternyata memiliki efek mematikan dan penyebaran yang sangat cepat. Hingga saat ini (08/06/2020), World Health Organization (WHO) melalui websitenya telah menyampaikan jumlah kasus yang terkonfirmasi sebanyak 6.881.352 orang, kematian terkonfirmasi 399.895 orang, yang mana tersebar di 216 wilayah diseluruh Negara di dunia. Untuk di Indonesia, update terakhir (08/06/2020) dari website Gugus Tugas Percepatan Penanganan Covid-19 didapati jumlah positif ada 32.033 orang, yang sembuh 10.904 orang dan yang meninggal 1.883 orang (covid.co.id).

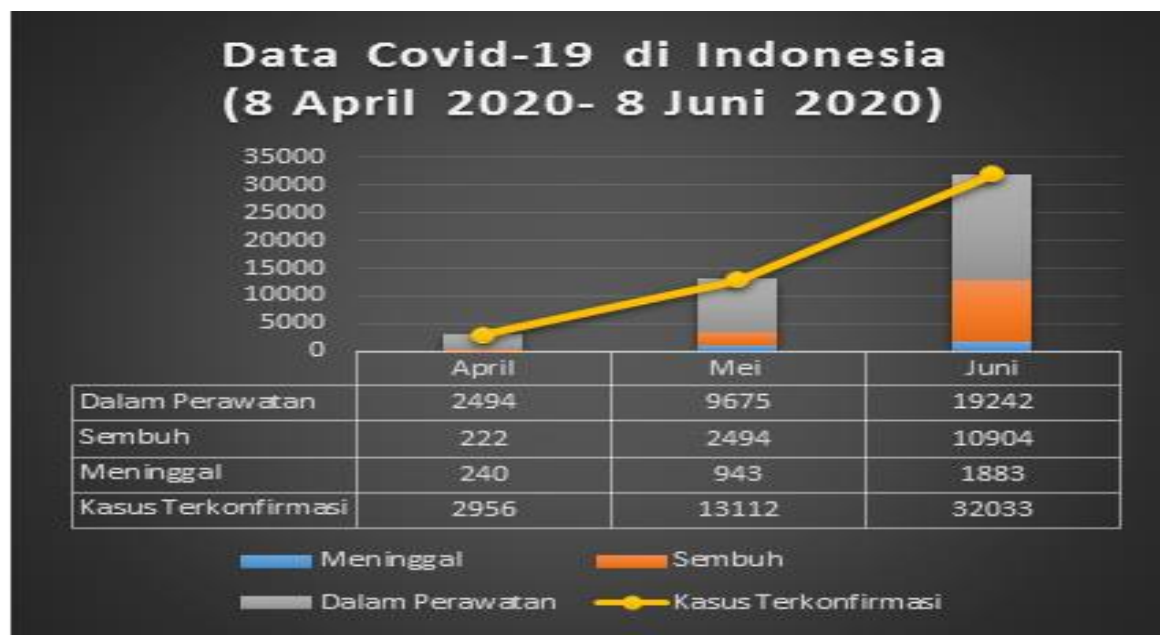

Gambar 1. Grafik Covid-19 Bulan April - Juni

Sumber: Hasil olah penulis dari data covid.co.id 
Dari data diatas terlihat bahwasanya kasus Covid-19 masih terus mengalami peningkatan. Adapun gejala-gejala dialami mereka yang positif Covid-19 adalah batuk (75,7\%), riwayat demam (50,7\%), demam (45,9\%), sesak nafas (40,7\%), lemas (34\%), sakit tenggorokan (30,9\%), dsb (covid.co.id). WHO juga mengatakan bahwa Covid-19 menular melalui orang yang telah terinfeksi virus tersebut dengan penyebaran melalui tetesan kecil dari hidung ataupun mulut mereka. Ketika penderita Covid-19 batuk atau bersin, kemudian mengenai mereka yang sehat baik dari media permukaan benda yang disentuh ataupun menyebar ketika terhirup oleh seseorang ketika berdekatan (CNBC Indonesia, 2020). Oleh karena itu, Covid-19 merupakan musibah yang hingga saat ini belum bisa diprediksi sampai kapan akan berakhir. Para ahli kesehatan juga tidak dapat memberikan jawaban pasti berapa lama dan berapa banyak korban yang akan jatuh akibat virus ini.

Jika melihat jumlah terkonfirmasi positif covid-19 yang terus mengalami peningkatan dan penyebaran yang sangat mudah terjadi, WHO merekomendasikan untuk menghentikan sementara kegiatan yang berpotensi menimbulkan kerumunan massa (Firman dan Sari, 2020). Pemerintah Indonesia dalam menghentikan laju Covid-19 juga mengeluarkan kebijakan serta statement berupa Work From Home (WFH), social distancing, Pembatasan Sosial Berskala Besar (PSBB) dan sebagainya, yang mana hal tersebut akan mempengaruhi sendi-sendi kehidupan masyarakat. Selain dari sisi kesehatan yang terdampak, diprediksi ada beberapa sektor yang berpotensi mengalami penurunan akibat virus ini, diantaranya pariwisata, transportasi, konstruksi, pendidikan, keuangan, dan sektor lainnya (Dcode EFC Analysis: in Egypt, 2020). Bukan hanya sektor barang dan jasa yang terdampak, namun hingga pada sektor spiritual keagamaan juga dipengaruhi oleh adanya pandemic covid-19 ini. Dalam hal ini, MUI sampai mengeluarkan Fatwa No. 14 tahun 2020 tentang penyelenggaraan ibadah dalam situasi terjadi wabah covid19.

Dengan melihat hal ini, jelas bahwasanya munculnya Covid-19 memiliki pengaruh yang sangat besar terhadap kehidupan masyarakat. Berangkat dari penjelasan tersebut, dilakukanlah penelitian secara mendalam mengenai pengaruh covid-19 terhadap beberapa sektor kehidupan, apa yang dirasakan dan bagaimana masyarakat mengatasi keterbatasan yang diakibatkan oleh covid-19. Adapun sektor yang akan dibahas adalah pendidikan, ekonomi dan keagamaan. Pengambilan sektor-sektor ini didasarkan pada sektor yang bersinggungan langsung dengan Covid-19 serta kebijakan yang dikeluarkan pemerintah untuk WFH, pemberlakuan social distancing, adanya surat edaran Kementrian Pendidikan dan Kebudayaan (Kemendikbud) Direktorat Pendidikan Tinggi No. 1 tahun 2020 dan munculnya fatwa MUI (tentang Covid19) yang memiliki kaitan langsung dengan sektor pendidikan, ekonomi dan juga keagamaan.

Kajian Literatur : Sistem Pembelajaran di Indonesia. Pada umumnya, sistem pembelajaran di Indonesia masih melibatkan sistem konvensional dimana memadukan pembelajaran tatap muka dengan media komunikasi multimedia. Namun, seiring perkembangan era teknologi, banyak sekolah khususnya di kota telah memanfaatkan internet. Menurut Lantip dan Rianto (2011) teknologi informasi adalah ilmu pengetahuan dalam bidang informasi yang berbasis computer dan perkembangannya sangat cepat. Pujilestari (2020) 
menjelaskan bahwa terdapat klasisfikasi pemanfaatan ICT kedalam tiga jenis yaitu sebagai media Pendidikan, sebagai sumber mencari informasi, dan terakhir sebagai sistem pembelajaran. Namun, penggunaan TI di Indonesia baru saja memasuki tahap mempelajari berbagai kemungkinan untuk pengembangan dan peneratpan TI untuk Pendidikan. Menurut Pujilestari (2020) terdapat istilah E-Education dimana ini adalah sebutan untuk penggunaan IT di bidang Pendidikan. Internet membuka sumber informasi yang sulit untuk dikases serta memungkinkan pengembangan layanan informasi yang lebih baik di Lembaga pendidikan.

Perekonomian Indonesia. Menurut Silpa Hanoabutun (2020) dampak yang ditimbulkan oleh Covid-19 terhadap perekonomian Indonesia saat ini sangat banyak, mulai dari sektor perusahaan, perdagangan, pariwisata, perhotelan dll. Kemudian juga terjadinya kesusahan berupa PHK dalam pekerjaan yang berakibat pada sulitnya pemenuhan kebutuhan sehari-hari karena tidak adanya penghasilan. Dalam kajian lain yang dilakukan oleh Eka Budiyanti (2020) mengatakan bahwa dampak yang ditimbulkan oleh Covid-19 pada perekonomian di China memiliki pengaruh pada perekonomian Indonesia, khususnya di sektor perdagangan dan pariwisata. Sejak Januari 2020 telah terjadi penurunan ekspor-impor dari dan ke China. Begitupun dengan jumlah wisatawan China yang mengalami penurunan cukup dratis. Beberapa upaya yang dilakukan adalah dengan melakukan ekspor ke negara lain, meningkatkan produksi dan konsumsi dalam negeri, serta meningkatkan wisatawan dalam negeri maupun luar dari China.

Dampak lain juga dirasakan oleh pebisnis berbasis platform online di Jakarta (Taufik dan Eka, 2020), dimana ditemukan ada beberapa dampak positif dan juga negatif dalam aktivitas bisnis mereka yaitu pertama, terdapat bisnis yang bertahan atau stabil seperti bisnis yang menggunakan model interaksi platfom online: pendidikan, pengantar makanan atau minuman, kebutuhan pokok, serta produk bagi kesehatan, dll. Kedua, bisnis yang mengalami penurunan seperti, kunjungan atau keberadaan konsumen ditempat yang sangat terdampak oleh covid adalah angkutan umum, pariwisata, perhotelan, ritel offline, pusat perbelanjaan, angkutan orang maupun barang. Sedangkan yang ketiga, akitivitas bisnis yang berkembang karena dinamika pasar dan penyesuaian model interaksi yang menggunakan platform aplikasi online seperti, bisnis telekomunikasi, belanja online (kebutuhan pokok dan produk kesehatan), farmasi, produk kesehatan, termasuk UMKM yang beralih secara inovatif memproduksi produk kesehatan yang dibutuhkan selama masa panemi Covid-19.

Amalia Shofiana (2020) mengatakan bahwa perekomomian Indonesia akibat Covid-19 menyebabkan lesunya omzet yang dihasilkan oleh UMKM, itulah mengapa pemerintah membantu dalam mengatasi hal ini. Namun kenyataannya, para pelaku UMKM ini yang dibutuhkan adalah kelancaran usaha. Program afiliasi berbasis virtual team dan membantu perekonomian negara sekaligus penerapan physical distancing dapat dilakukan para UMKM, dimana program afiliasi ini hanyalah membutuhkan gadget, sehingga mengurangi biaya karyawan dan juga tidak keluar rumah dan afiliasi ini hanya akan mengambil keuntungan sesuai dengan berapa produk yang terjual. Sehingga program afiliasi ini akan berdampak baik bagi perekonomian negara 
maupun kehidupan para pelaku UMKM serta mengurangin pengangguran dengan tetap menerapkan WFH (work from home).

Aknolt Kristian Pakpahan (2020) mengatakan terdapat beberapa strategi yang dapat disiapkan untuk jangka pendek seperti bantuan keuangan, baik dalam bentuk pinjaman lunak ataupun tunai secara langsung yang melibatkan pemerintah dan pihak swasta, sedangkan kebijakan jangka panjang yaitu seperti pengenalan dan penggunaan teknologi digital bagi UMKM sekaligus dalam persiapan memasuki Era Industri 4.0. Chairul Iksan Burhanuddin dan Muhammad Nur Abdi (2020) mengatakan bahwa perekonomian global tidak bisa jika hanya diukur dengan sebatas lingkup ekonomi itu sendiri, virus corona inilah yang menjadi bukti bahwa kesehatan dapat menyebabkan ketidakstabilan perekonomian suatu negara dalam skala dunia. Dalam menghadapai dampak ekonomi perlu mempertimbangkan adanya dana cadangan atau talangan dalam mempersiapkan ketidakpastian ekonomi global yang sumbernya tidak dapat diprediksi apa itu nantinya.

Praktik Keagamaan di Indonesia. Selain dari sektor perekonomian dan pendidikan, dampak yang ditimbulkan oleh Covid-19 juga dirasakan dalam praktik spritualitas manusia. Seperti halnya yang dikatakan oleh Hariman, dkk (2020), melihat dari sudut pandang sains dan agama dalam menyikapi permasalah covid-19 perlu berpikir posotif dan mengambil hikmah atas kejadian tersebut. Dalam Islam, Allah menciptakan, memelihara dan mengatur segala alam semesta dan seluruh isi beserta makhluk didalamnya. Dengan begitu manusia-pun dapat mengatasi kerusakan yang terjadi dengan konsep Islam. Dadan, dkk (2020) menemukan bentuk pesan dakwah yang disampaikan oleh ormas islam terkait kegiatan dalam menghadapi pandemi, berita opini, opini dan panduan organisasi seperti fatwa, himbauan, dan surat edaran. Dalam pesan dakwah yang dibuat oleh pengurus pusat maupun gugus tugas khusus penanganan Covid-19, lembaga, organ otonom, perguruan tinggi, rumah sakit dan pengurus Ormas di berbagai daerah tersebut berkaitan soal muamalah, ibadah, dan juga aqidah. Hal ini memberikan keunikan tersendiri terkait kajian pada masa pandemi.

Hasbiyallah, dkk (2020) menyatakan bahwa Majelis Ulama Indonesia (MUI) berperan dalam pengambilan keputusan pemerintah terkait soal agama, yang mana terdapat dua pandangan masyarakat untuk mengikuti atau menolak keputusan yang difatwakan oleh MUI terkait beribadah dirumah, dan terdapat pandangan ulama indonesia yang beragam tentang aspek ibadah dalam kondisi darurat yang disebakan oleh covid-19. Ibadah yang awalnya wajib berubah menjadi haram, makruh ataupun mubah. Pandangan masyarakat terhadap fatwa tersebut, pertama ekstrimisme dalam bentuk ketaatan untuk tetap dirumah. Kedua, mengambil jalan tengah dirumah dan di tempat ibadah dan ketiga liberal yaitu penolakan dari intruksi tetap dirumah saja. Dalil yang mereka gunakan adalah dalil dari ulama yang telah memberikan informasi kepada mereka dari aspek yang berbeda. Abdul Syatar, dkk (2020) menyampaikan bahwa moderasi islam dalam ibadah saat covid-19 adanya rukhsah atau keringanan dan juga kaidah menghindari kemudharatan lebih penting dibandingkan melaksanakan, dengan tujuan tercapai mashlahat. Adapun bentuk rukhsah tersebut seperti tidak melakukan shalat kemasjid atau ibadah lainnya, sehingga sebaiknya kita melakukan aturan yang ada dan mengambil rukshah tersebut. 


\section{B. PENGARUH COVID-19 DI SEKTOR PENDIDIKAN}

Adanya Pandemic Corona di Indonesia ini menyebabkan berbagai kesulitan pada dunia Pendidikan. Mulai dari pembelajaran sistem online hingga penghapusan ujian nasional bagi para pelajar. Adanya proses pembelajaran secara daring ini tak lepas dari pesatnya perkembangan teknologi informasi. Pasca mewabahnya pandemic covid-19 ke Indonesia pada pertengahan Maret tahun 2020 membuat pemerintah meniadakan sementara pembelajaran tatap muka. Hal ini kemudian menimbulkan berbagai kendala. Salah satu pelajar yang kecewa dengan kasus ini yaitu Kaludius Serko, pelajar di salah satu SMK di Surabaya "Saya merasa kenapa ujian kompetensi untuk SMK harus diberhentikan sementara, padahal saya belum dapat sertifikat dari perusahaan, itu yang bikin saya agak sesak" ungkapnya dalam VoA Indonesia (07/05/2020). Penetapan sekolah melalui daring ini menimbulkan banyak pro-kontra di dalamnya. Bagi siswa dari kelas ekonomi menengah kebawah kebutuhan untuk memenuhi fasilitas belajar secara online sangat berat. Mulai dari kuota internet hingga perangkat yang mendukung. Dengan berbagai keterbatasan siswa tersebut, menyebabkan pembelajaran menjadi terus terganggu. Ketidaksiapan sekolah/madrasah maupun orang tua melaksanakan pembelajaran daring menjadi faktor utama kekacauan ini. Fasilitas daring seperti laptop, komputer, ataupun handphone seharusnya dipersiapkan terlebih dahulu oleh pemerintah melalui sekolah. Hal ini dilakukan agar proses belajar mengajar online tidak terhambat. Seperti halnya yang dialami oleh Hafshoh Bintang Mumtaza (16), menyampaikan bahwa: "kesulitan yang dihadapi saat belajar online adalah terkadang sinyal jelek dan peraturan dari sekolah yang menetapkan harus menggunakan hp orang tua sebagai bentuk pengawasan, sehingga saat belajar online hanya bisa menggunakan satu hp untuk dipakai 5 orang anak (kakakberadik)" ungkapnya dalam wawancara (13/o6/2020). Maka, perlulah evaluasi akan kebijakan dan perlunya bantuan dari pemerintah.

Kendala selanjutnya yaitu murid belum pernah mengalami budaya belajar secara daring karena selama ini murid telah terbiasa bertatap muka dengan gurunya. Dengan adanya metode pembelajaran daring ini, membuat para murid dan guru untuk beradaptasi menghadapi perubahan ini. Kemudian, menurut Purwanto, dkk (2020) dampak yang juga di alami murid yakni adanya kejenuhan ketika sekolah diliburkan. Sebelum pandemic, mereka terbiasa berinteraksi sosial baik dengan teman-temannya maupun gurunya. Ketika sekolah dipaksa diliburkan dengan jangka panjang, murid akan kehilangan jiwa sosialnya. Menurut Zapalska (2006) jika seorang siswa tertetu belajar terbaik dengan cara tertentu, ia harus dihadapkan pada berbagai pengalaman belajar untuk menjadi pembelajar online yang lebih fleksibel. Oleh karena itu, perlu adanya pembiasaan terlebih dahulu baik pada siswa maupun guru dalam proses pembelajaran online.

Berikut beberapa wawancara yang peneliti lakukan kepada beberapa siswa untuk melihat tanggapan mereka terkait Covid-19 dan sekolah online. Pertanyaan yang diajukan yaitu nama, usia, tingkatan pendidikan, kelas, tanggapan terkait sekolah berbasis online, kesulitan yang dihadapi saat sekolah online, ada ketakutan/trauma atau tidak untuk kembali sekolah, kondisi pembelajaran seperti apa yang diharapkan. Adapun hasil wawancaranya yaitu: 
1. Nur Zakia Ahmat yang merupakan siswa kelas XI MAN 2 Model Pekanbaru. Zaskia menyatakan bahwa untuk beberapa alasan dirinya menyukai kelas berbasis online karena proses belajar yang mudah dan praktis, namun disisi lain ia merasa ada beberapa pelajaran terkait materi-materi yang sulit untuk dipahami karena penyampaian yang terbatas dari guru. Selain itu, ia merasa tidak nyaman karena mengalami proses yang berbeda dari kebiasaan sekolah selama ini. Zaskia juga merasa belajar online sangat tidak efektif dan baginya sekolah online hanya dimanfaatkan sebagai formalitas sekolah. Sebagai contoh tidak efektifnya kelas online tersebut adalah banyaknya celah untuk mencontek serta masih banyak guru yang kesulitan dalam memberikan pemahaman kepada siswa sebab akses yang terbatas. Tidak hanya itu, kesulitan dan hal yang tidak disukai dari sekolah online menurut Zaskia adalah terkadang guru banyak memberikan tugas/PR sebagai partisipasi kelas, kesulitan dalam hal absensi dan sinyal yang tidak mendukung. Namun, kemudahan yang diperoleh dari sekolah secara online ini baginya yaitu kemudahan dalam proses belajar mengajar, tidak perlu banyak bawa buku ke sekolah, dll. Ketika ditanya tentang perasaannya akan sekolah, Zaskia menyatakan bahwa ia rindu sekolah, rindu dengan proses belajar mengajar dengan tatap muka yang diselingi dengan candaan, tidak luput juga baginya untuk merindukan jajanan kantin dan bertemu dengan teman-teman. Disisi lain, ia juga khawatir untuk sekolah kembali karena kondisi belum pulih. Namun sekolah tetap harus dijalankan meski dengan peraturan khusus untuk mencegah penularan Corona. Zaskia berharap sistem yang ramah dan penuh toleransi, dimana guru bersemangat untuk mengajar dan murid juga semangat untuk menuntut ilmu. Dia juga menginginkan sekolah online menjadi solusi terbaik dikondisi pandemic ini.

2. Mellisa Triwardani merupakan siswa SMA kelas $\mathrm{X}$ di MAN 2 Model Pekanbaru. Mellisa merasa bimbang antara suka atau tidak dengan adanya sekolah online. Ia suka dengan sekolah berbasis online dengan pertimbangan bahwa siswa dilatih menjadi lebih bijak dan terlatih dalam menggunakan teknologi, akan tetapi disisi lain ia tidak suka karena tidak semua siswa dapat memahami materi pembelajaran secara virtual, melainkan ada yang harus dengan audio-visual. Sehingga, dalam hal ini baginya sekolah berbasis online kurang tepat untuk diterapkan mengingat kemampuan setiap siswa yang berbeda dalam memahami pelajaran dan kurang efektif dibandingkan dengan pembelajaran tatap muka. Dengan pembelajaran sekolah berbasis online ini kesulitan yang dialami Mellisa yaitu terkadang merasa kurang memahami materi, tetapi kemudahan/manfaat via online ini yaitu membuat anak-anak dapat diawasi orang tuanya ketika belajar. Dibalik itu semua, Mellisa merasa rindu untuk masuk sekolah dan aktifitas belajar bersama teman-temannya, namun masih takut akan wabah yang belum tau kapan berakhirnya. Lalu ia berharap agar kedepannya tersedia media pembelajaran yang didalamnya guru dapat menjelaskan, menerangkan materi pembelajaran dengan baik, adanya sesi tanya jawab sebagai bentuk keaktifan kelas serta sebagai bentuk pahamnya siswa akan pelajaran. 
Selain siswa, guru juga tidak terlepas dari dampak yang diakibatkan karena pandemic ini. Menurut Purwanto, dkk (2020) terdapat beberapa problem yang dihadapi oleh guru. Pertama, tidak semua guru mahir menggunakan teknologi internet atau media sosial sebagai sarana pmbelajaran. Kedua, yaitu tidak tersedianya sarana dan prasarana yang menunjang program belajar online. Ketiga, perlunya adaptasi para guru dalam proses pembelajaran daring.

Selain itu, di tengah masa persiapan "New Normal”, pemerintah mencoba mengaktifkan Kembali seluruh sekolah di Juli nanti, padahal jumlah kasus penyebaran virus corona di Indonesia masih terus meningkat. Kebijakan kembali masuk sekolah ini ditetapkan oleh Kementerian Pedidikan dan Kebudayaan. Namun hal ini tetap dikoordinasikan dengan pemerintah daerah masing-masing. Menurut harian Kompas (30/05/2020), hingga 28 Mei 2020 terdapat paling tidak 108 kabupaten/kota di Indonesia yang masuk kategori zona hijau, atau sekitar $21 \%$ dari total 514 kabupaten atau kota yang ada. Hal ini yang kemudian menyebabkan orang melakukan Gerakan mendukung petisi tunda masuk sekolah. Menurut direktur Jenderal WHO Tedros Adhanom dalam harian Kompas (Senin, 01/06/2020) mengatakan ada enam kriteria yang harus dipenuh jika pemerntah ingin melakukan pelonggaran. Pertama, laju penyeberan harus terkendali. Kedua, sisem Kesehatan berfungsi dengan baik dalam mendeteksi, memeriksa, mengisolasi, merawat setiap kasus Covid-19, dan melacak setiap kontak kasus. Ketiga, resiko penularan di tempat-tempat tertentu terutama fasilitas umum dapat diminimalkan. Keempat yaitu adanya tindakan pencegahan penularan di tempat umum dapat di jalankan dengan disiplin. Kelima, kasus impor bisa dikendalikan. Yang terakhir, masyarakat sepenuhnya teredukasi tentang pandemic ini.

\section{PENGARUH COVID-19 DI SEKTOR PEREKONOMIAN}

Mewabahnya pandemic Covid-19, berdampak pada rusaknya tatanan perekonomian negara di berbagai dunia. Secara garis besar, di pasar keuangan Indonesia setidaknya terdapat dua indikator utama yang memperlihatkan dampak dari Covid-19 ini yaitu pertama, dari sisi nilai tukar Rupiah terhadap Dollar AS, dimana nilainya mencapai 16.575 Rupiah per Dollar AS yang tercatat pada 23 Maret 2020 (Grafik 1). Kedua, Bursa Efek Indonesia (BEI) juga mengalami pukulan telak akibat wabah ini. Jakarta Composite Index (JKSE) yang memiliki nilai stabil disekitar 6.200 hingga pada bulan Januari akhir, kemudian mengalami penurunan drastis menjadi 4.000 di minggu terakhir bulan Maret sebelum rebound ke angka 4.500 pada bulan April 2020 yang disebabkan adanya sentiment positif dari beberapa produsen farmasi seperti Sidomuncul, Indo Farma, Kimia Farma dan Kalbe Farma karena melonjaknya permintaan terhadap produk-produk kesehatan. 


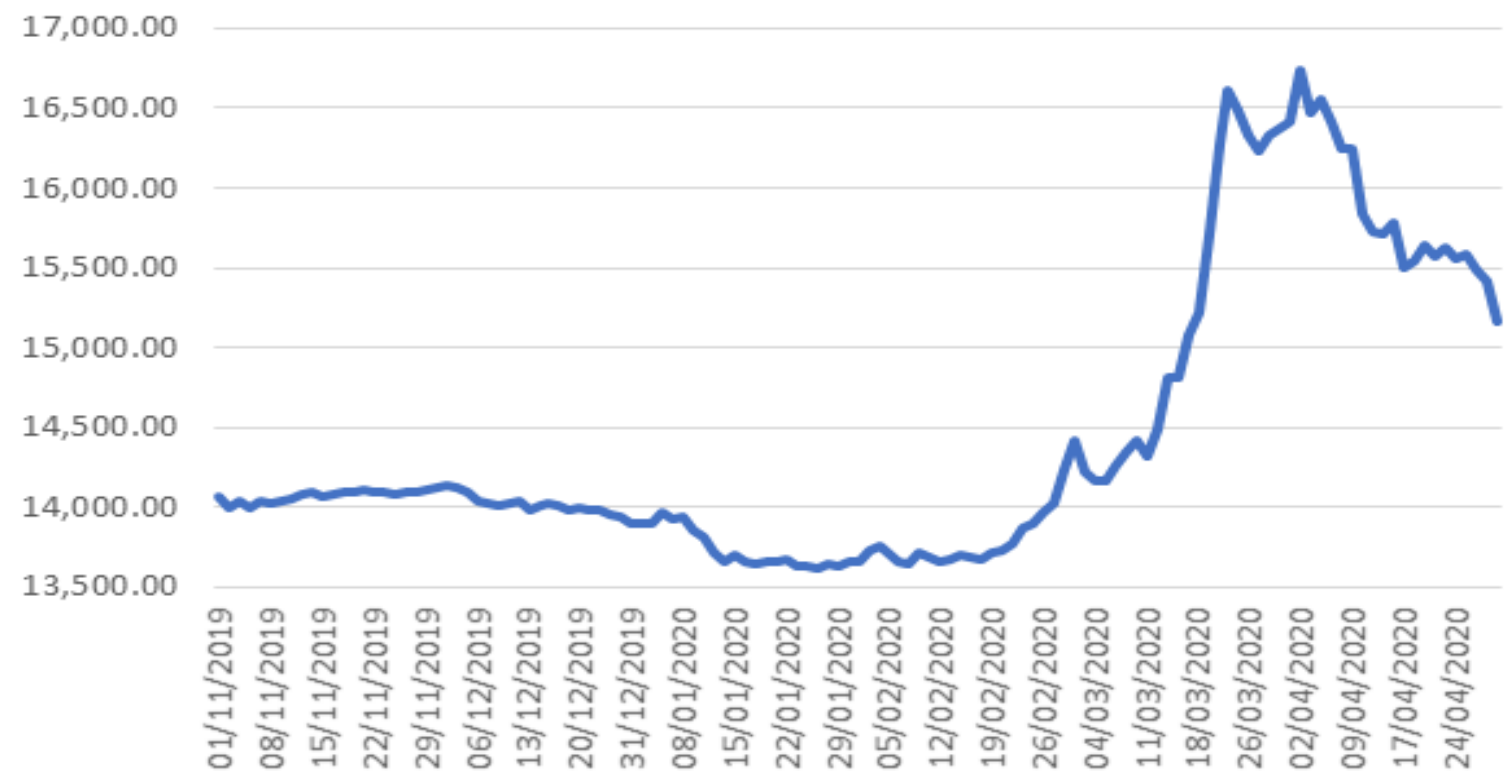

Gambar 2. Nilai Tukar Rupiah Indonesia Terhadap Dolar AS, November 2019 hingga April 2020

Sumber: Bank Indonesia

Selain itu, Covid-19 juga menimbulkan economic shock yang mempengaruhi perekonomian baik secara perorangan, rumah tangga, Usaha Mikro Kecil Menengah (UMKM), hingga perusahaan besar, dari skala lokal, nasional sampai dengan skala global (Taufik dan Eka, 2020). Seperti halnya yang terjadi pada UMKM, dimana KemenkopUKM melaporkan bahwa terdapat sekitar 56\% UMKM melaporkan terjadinya penurunan penjualan, 22\% melaporkan terkait permasalahan pembiayaan, $15 \%$ melaporkan adanya masalah terkait pendistribusian barang dan 4\% melaporkan kesulitan memperoleh bahan baku mentah (Rahman, 2020).

\section{LAPORAN UMKM TERHADAP DAMPAK COVID-19}

घPenurunan Penjualan $\quad$ Masalah Pembiayaan $\quad$ Masalah Distribusi Barang $\square$ Masalah Bahan Baku

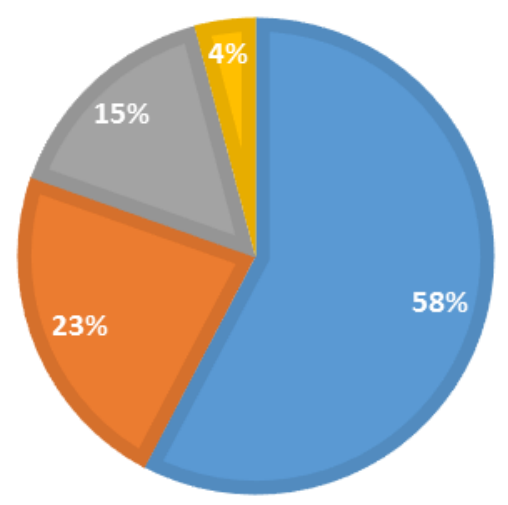

Gambar 3. Dampak Covid-19 Terhadap UMKM 
Hal di atas diperkuat dengan hasil wawancara yang dilakukan penulis ke para pedagang dan ojek online. Adapun pertanyaan yang diajukan penulis kepada pedagang yaitu mulai dari nama, usia, status, jumlah tanggungan hidup, lama bekerja sebagai pedagang, jam kerja, penghasilan sebelum dan sesudah Covid-19, kendala yang dihadapi, cara mereka survive dari kondisi Covid-19, trauma atau ketakutan yang dirasakan, merambah ke sektor online atau tidak, bantuan yang diterima dari pemerintah, tanggapan terhadap kebijakan serta hikmah yang didapat perihal Covid-19. Adapun hasil wawancara yaitu:

1. Fazza yang merupakan pedagang batu alam dari Surabaya, memiliki tanggungan hidup sebanyak 5 orang. Beliau sudah berada di bisnis ini lebih kurang 1 tahunan, yang mana pekerjaannya biasa di mulai dari pukul o8.0o16.00. Diketahui bahwasanya penghasilan sebelum Covid-19 bisa mencapai Rp. 3.000.000,- per hari, namun semenjak Covid-19 penghasilan hanya sekitar Rp. 300.000,-. Beliau merasa bahwa agak kesulitan karena harus menggaji pegawainya yang mana dalam seminggu harus mengeluarkan uang Rp. 1.500.000,- lebih. Selain itu, beliau menyampaikan bahwa kendala yang dihadapinya seperti toko sepi pelanggan, proyek tidak jalan dan otomatis utang-utang proyek tidak terbayar (tertunda). Cara survive yang mereka lakukan hanya ikhtiar dan berdoa agar masalah Covid-19 ini segera berlalu. Beliau mengatakan bahwa kebijakan yang pemerintah keluarkan cukup plinplan dan berharap ada ketegasan dari pemerintah dalam menangani dan membantu masyarakat. Namun, disamping segala permasalahan yang ada, Mbak Fazza mengambil hikmah bahwa kita dalam hal ini ditegur Allah agar semuanya dapat perbanyak sabar dan bersyukur.

2. Siti Hidayah (41) merupakan pedagang yang sudah berkecimpung selama 25 tahun. Dagangan beliau saat ini yaitu pakaian dan dalaman jilbab di Tarakan, dengan tanggungan hidup sebanyak 5 orang anak dan semuanya sedang menempuh pendidikan. Mbak Siti biasanya di hari normal mulai berdagang pukul o8.00 sampai 22.00, tetapi ketika Covid-19 beliau berdagang mulai dari jam o8.00 sampai 15.00 sore. Penghasilan beliau biasanya dalam sehari bisa mencapai Rp.700.00o,- akan tetapi setelah adanya Covid-19 penghasilan yang diterima rata-rata hanya Rp. 50.000,sampai dengan Rp.100.000,- per harinya. Bahkan biasanya selama ramadhan hingga hari raya menjadi ladang panen besar dengan penghasilan bisa mencapai puluhan juta, namun dengan kondisi kini menjadi sulit. Kendala yang dihadapi selama pandemi ini yaitu jualan tidak fokus karena di kejar Satpol PP dan petugas gabungan yang mana memerintahkan untuk cepat tutup, sehingga sering juga tidak mendapat penghasilan. Mbak Siti menyampaikan bahwa cara yang dilakukan untuk bisa bertahan adalah menjual barang dagangan dengan harga asli, sehingga tidak ada untung yang diperoleh. Hal yang terpenting baginya saat pandemi seperti ini adalah bertahan hidup. Selain itu, beliau menyampaikan bahwa tidak ada bantuan yang diterima dari pemerintah dan beliau juga menyatakan kebijakan yang pemerintah keluarkan sangat merugikan rakyat yang penghasilannya tidak tetap seperti pedagang, ojek online, kuli, dsb, maka diperlukan perhatian khusus untuk hal ini. Diluar dari semua permasalahan yang dihadapinya, dampak positif dari munculnya Corona Virus ini adalah semakin rajin untuk membaca Al-Qur'an hingga bisa khatam 3 kali dalam sebulan serta semakin maksimal dalam mengajarkan Al-Qur'an pada ponakan-ponakannya. 
3. Burhan (28) merupakan seorang pedagang sembako di Jombang. Beliau memiliki tanggungan hidup sebanyak 5 orang. Mas Burhan sudah berdagang sembako selama 5 tahun. Beliau biasanya bekerja dari jam 06.0o. Adapun penghasilan yang didapat pada kondisi normal yaitu Rp. 1.000.0oo,- per harinya, sedangkan ketika kondisi Covid-19 seperti ini pendapatan hanya Rp. 400.000,-. Kendala yang dihadapi disaat seperti ini adalah sepi pembeli. Untuk bisa survive dari keadaan yang sulit ini biasanya saya mengandalkan dari penghasilan di pekerjaan lainnya. Selain itu, beliau merasa takut jika tertular virus ini, karena bersinggungan langsung dengan banyak orang. Mas Burhan juga menyatakan bahwa hingga saat ini beliau belum menerima bantuan dari pemerintah dan berharap agar segera ada tindakan yang berefek baik bagi masyarakat terutama pedagang. Namun demikian, beliau mengatakan bahwa Covid-19 memberikan hikmah yaitu beliau jauh lebih bisa banyak beribadah dengan khusyuk dan tenang.

Selain dari pedagang juga dilakukan wawancara kepada ojek online (Ojol) yang pekerjaannya dominan bersinggungan langsung dengan banyak orang. Adapun pertanyaan yang diajukan terkait dengan nama, status, tanggungan hidup, lama bekerja menjadi ojol, jam kerja, penghasilan yang di peroleh sebelum dan sesudah adanya Covid-19, kendala yang dihadapi, cara survive dikondisi Covid-19, ketakutan atau trauma yang dihadapi, jumlah pelanggan sebelum dan sesudah Covid-19, adakah menerima bantuan pemerintah, tanggapan terkait kebijakan pemerintah serta hikmah apa yang dirasakan.

1. Gilang Ramadhan (22) merupakan driver ojek online di Pekanbaru. Beliau sudah bekerja menjadi ojol selama 3 tahun 4 bulan dan biasanya mulai narik dari pukul 09.00 pagi. Pendapatan yang diterima dikondisi normal per harinya bisa sampai Rp. $200.000-$ Rp. 250.000,- atau sebanyak 20 orderan - Tetapi, semenjak adanya Covid-19 penghasilan berkurang menjadi Rp. 75.000 - Rp. 150.000,- per harinya dengan jumlah orderan hanya berkisar 10-12. Beliau menyampaikan bahwa saat pandemic seperti ini kendala yang dihadapi adalah berkurangnya spot orderan karena banyak resto yang tutup. Satu-satunya cara yang beliau lakukan untuk dapat bertahan dalam kondisi ini yaitu dengan mengurangi pengeluaran. Selain itu, beliau juga merasa takut dan trauma dengan berkurangnya orderan, banyaknya hal yang dibatasi serta takut terdampak virus. Dari segi kebijakan pemerintah, beliau menyatakan bahwa ada nilai positif dan negatifnya. Dampak positif atas kebijakan pemerintah dengan menerapkan PSBB mampu menekan angka positif Covid-19, sedangkan dampak negatifnya adalah banyaknya penutupan ruas jalan membuat para ojol kesulitan karena yang seharusnya jarak tempuh pengantaran pemesanan dekat menjadi jauh dibuatnya. Namun, walaupun demikian dengan adanya Covid-19 hikmah yang beliau ambil adalah membuat kita dan banyak orang menjadi saling peduli satu sama lainnya.

2. Nur Wahyudi, merupakan driver ojol di Yogyakarta. Beliau menyampaikan bahwa sudah lama menjadi ojol. Biasanya beliau buka aplikasi setelah subuh, tapi baru dapat orderan ketika jam 09.00 pagi dan biasanya selesai narik di jam 22.00. Beliau sangat merasakan terjadinya penurunan penghasilan ketika hadirnya Covid-19. Ketika kondisi normal, penghasilan 
bisa berkisar antara Rp. 150.000,- hingga Rp. 250.000,- akan tetapi ketika Covid-19 penghasilan hanya berkisar Rp. 65.000 - Rp. 130.00o,-. Beliau juga menyatakan bahwa saat ini dari aplikasi, bonus yang diperoleh hanya berupa tambahan ketika pendapatan kurang dari Rp. 65.000,-. Misalnya, dalam sehari beliau hanya mendapat penghasilan Rp. 45.000,- nanti dari pihak aplikasi ojol akan menambahkan sebesar Rp. 20.000,-. Jadi intinya dalam sehari setidaknya memiliki pendapatan Rp. 65.000,-. Di kondisi pandemi seperti ini kendala yang biasa dihadapi adalah banyaknya ruas jalan ditutup, orderan sedikit karena hanya menerima order makanan sedangkan anter orang tidak bisa, bahkan masih ada orderan fiktif yang buat beliau kesal karena bila tidak diambil akan berefek pada peforma yang turun. Untuk bisa bertahan beliau melakukan press biaya hidup, selektif dalam beli-beli sesuatu, dan mengurangi pengeluaran. Dari segi kebijakan pemerintah, beliau berharap agar segala sesuatunya berefek baik bagi masyarakat dan segera kembali normal. Hikmah yang beliau ambil dari kejadian pandemic ini yaitu beliau jadi lebih sering beribadah.

\section{PENGARUH COVID-19 DI SEKTOR KEAGAMAAN}

Covid-19 yang hadir bukan hanya memangsa sektor ekonomi dan juga pendidikan, tetapi juga keranah spiritualitas. Pandemi ini memaksa kegiatan keagamaan yang ada untuk dapat beradaptasi lantaran adanya larangangan perkumpulan massa. Mulai dari keuskupan dan gereja diseluruh dunia ramairamai membatalkan kegiatan keagamaan. Sinagoga di Amerika Serikat dan Eropa menutup pintu. Pelaksanaan Festival Purim umat Yahudi dirayakan separuh hati, sama halnya dengan perayaan Holi oleh umat Hindu India. Bahkan Mouhanad Khorchide yang merupakan intelektual islam Jerman meminta umat islam seluruh dunia merujuk pada penutupan kakbah di Mekkah dan melakukan ibadah di rumah (DW, Liputan 6, 2020)

Wawancara yang dilakukan kepada beberapa pemeluk agama bertujuan untuk mengetahui lebih dalam tanggapan mereka mengenai pengaruh Covid-19 terhadap aktivitas keagamaan serta bagaimana mereka melawatinya, maka diajukan beberapa pertanyaan diantaranya yaitu terkait nama, usia, agama yang dianut, pekerjaan, tanggapan mereka akan ibadah yang dilarang pelaksanaannya di rumah ibadah, trauma/ketakutan apa yang muncul, kegiatan atau tradisi agama apa yang terdampak, bagaimana survive dari kondisi ini, tanggapan terkait kebijakan pemerintah mengenai pengaturan peribadatan serta hikmah yang diambil dari adanya peristiwa covid-19. Adapun hasilnya adalah:

1. Milka (21) dan Nadya (22), merupakan mahasiswa yang beragama Kristen Protestan. Mereka menyampaikan bahwa ketika Covid muncul, dampaknya adalah ibadah tidak bisa dilakukan di gereja, sehingga terasa kurang hikmat dan aneh pada awalnya karena ibadah via streaming. Tetapi, lama kelamaan sudah mulai terbiasa. Kegiatan dan tradisi agama yang terdampak Covid yaitu seperti Ibadah Jumat Agung dan Paskah yang mana merupakan salah satu event besar dalam agama Kristen dan lagi-lagi pelaksanaanya secara live streaming, hal tersebut terasa lebih aneh dibandingkan ibadah biasa hari minggu. Ketika ditanya terkait trauma atau ketakutan Nadya 
mengatakan bahwa dia takut dan khawatir bila Covid berkembang menjadi penyakit yang lebih agresif dan mematikan. Sedangkan Milka tidak terlalu takut, dia hanya berpesan untuk terus berhati-hati dan menerapkan protocol kesehatan yang diperintahkan. Lalu, untuk bisa survive dari keadaan ini, mereka berusaha mengikuti aturan yang ada, terus berdoa, membaca alkitab, berserah kepada Tuhan serta optimis bahwa hal baik akan datang satu persatu. Selanjutnya, dari sisi peraturan pemerintah mereka sepakat bahwa aturan untuk melaksanakan ibadah di rumah adalah hal yang tepat, tinggal bagaimana kita sebagai umat/masyarakat mematuhi aturan tersebut agar situasi dapat segera membaik. Diluar dari banyaknya masalah yang muncul akibat Corona, hikmah atau dampak positif yang dapat diambil oleh Milka yaitu lebih banyaknya waktu bersama keluarga, istirahat cukup serta hemat keuangan, sedangkan Nadya dengan adanya Covid malah bisa belajar masak dan menghemat uang.

2. Bunga Thuba S (24) merupakan mahasiswa beragama Islam. Terkait dengan kegiatan ibadah semenjak munculnya Covid membuatnya sedih karena bukan hanya aktivitas wajib seperti shalat, namun kegiatan kajian, pembelajaran, dll terhenti dan hanya bisa memanfaatkan akses kajian dari beberapa platform. Selain itu yang sangat sedih, hadirnya Covid juga bertepatan dengan pelaksanaan ibadah ramadhan. Akibatnya segala kegiatan ramadhan seperti puasa, tarawih, tadarus hingga hari raya semua dilakukan di rumah. Bahkan yang biasanya di Jogja sering dilakukan buka bersama di masjid, sekarang diganti dengan sistem take a way. Selain itu, munculnya wabah ini membuat ia merasa cukup takut di awal-awal pandemic, tetapi Alhamdulillah tidak berlanjut pada trauma. Untuk bisa bertahan dari kondisi ini, hal yang dilakukan secara spiritual yaitu dengan Ibadah Shalat wajib dan sunnah, mendengarkan kajian/ceramah agama di Youtube, Live Instagram, mengaji, berdoa dan berzikir setiap saat. Kemudian ia juga menyampaikan bahwa kebijakan pemerintah untuk melakukan pelarangan sementara tidak beribadah di Masjid sudah sangat tepat, hal ini sesuai dengan kisah tentang Wabah Tha'un yang terjadi di masa Rasulullah. Lalu, hikmah yang dapat diambil dari munculnya wabah ini adalah ia dapat merasakan kenikmatan berkumpul dengan keluarga, diberikan kesehatan untuk terus beraktivitas dirumah, dll.

3. Kristony Meindika P (23) adalah mahasiswa beragama Hindu. Ia tidak khawatir dengan ibadah yang dilakukan di rumah, baginya ibadah bisa dimana saja asalkan tepat waktu. Selain itu, ia mengatakan tidak terlalu takut atau trauma dengan adanya wabah ini. Baginya asalkan mengikuti aturan pemerintah dan protocol kesehatan, semua akan dapat dihadapi dengan baik. Untuk aturan ibadah, pemerintah sudah melakukan yang terbaik dan kita tinggal melaksanakan ibadah di rumah dengan kesediaan teknologi. Baginya hikmah yang didapat ketika Covid adalah bisa memperoleh banyak waktu luang untuk beristirahat dan refleksi diri akan rencana-rencana kedepan.

4. SD (inisial) adalah seorang pelajar beragama Buddha. Kehadiran Covid membuatnya merasa sedih dan kecewa karena tidak dapat beribadah di vihara. Selain itu, semua kegiatan yang biasanya dilakukan beramai-ramai di vihara seperti kebaktian, perayaan hari raya (waisak, asadha, kathina, magha puja), dan kegiatan organisasi agama jadi terhambat serta 
pelaksanannya dilakukan di rumah masing-masing dengan live streaming. Kemudian dampak dari adanya covid yaitu membuatnya lebih berhati-hati terhadap hygiene ketika berada di luar rumah. Untuk bisa survive dari hal ini secara spiritual ia biasanya melakukan ibadah di rumah bersama keluarga ataupun sendiri dengan live streaming youtube atau di platform lain. Lalu, terkait dengan kebijakan pemerintah ia menyampaikan bahwa kebijakan yang dikeluarkan terkait pengaturan peribadatan sudah cukup baik karena memang sebaiknya ada physical distancing. Namun, dari segala hal yang dialami hikmah yang dapat ia ambil adalah perkembangan tekonologi khususnya digital berkembang sangat pesat. Semakin banyak terobosan/alternative baru yang dapat mempermudah kegiatan sehari-hari.

\section{E. KESIMPULAN}

Beberapa dampak yang dirasakan murid dan guru pada proses belajar mengajar selama masa pandemic ini adalah sarana dan prasarana yang belum memadai, kemampuan menggunakan teknologi, serta belum terbiasanya pembelajaran jarak jauh. Oleh karena itu sebaiknya sekolah dan instansi terkait mempersiapkan fasilitas pembelajaran online, selain itu dukungan orang tua kepada anak-anaknya juga diperlukan untuk membantu anak berdaptasi dalam budaya belajar jarak jauh ini.

Dari sudut pandang perekonomian, Indonesia sedang mengalami tekanan diberbagai jenis usaha terutama pada perdagangan dan ojek online. Penghasilan yang menurun membuat mereka harus kreatif untuk dapat survive bahkan harus mampu melawan ketakutan terhadap Corona dengan berbagai cara seperti menjual dagangan dengan harga dasar, menekan biaya hidup, hingga mengurangi konsumsi. Tidak hanya itu, kebijakan yang pemerintah keluarkan dalam menangani kasus ini belum mampu mengakomodir kesejahteraan masyarakat, sehingga sangat diperlukan evaluasi kebijakan. Maka dalam hal ini perlu koordinasi yang baik antara para kepala pemerintah baik di daerah, provinsi dan pusat dalam membuat suatu kebijakan serta kerjasama dengan para pedagang dan perusahaan ojol agar dapat menstimulus pendapatan dan perolehan bantuan.

Tidak hanya ekonomi dan pendidikan, namun sektor spiritual beragama juga diajak bekerjasama dalam penanganan Covid. Segala bentuk kegiatan ibadah yang sifatnya mengumpulkan massa dilarang sementara waktu hingga kondisi menjadi lebih baik. Banyak dari umat-umat beragama merasa sedih karena tidak bisa beribadah dan melakukan tradisi keagamaan seperti biasanya. Secara tidak langsung, Covid mendorong kegiatan keagamaan untuk beradaptasi. Sehingga muncullah kebijakan untuk melakukan ibadah di rumah, seperti agama islam dengan ibadah shalat 5 waktu, tarawihnya dan hari rayanya, agama Kristen dengan ibadah mingguan, jumat agung dan paskah secara live streaming, begitu pula dengan Hindu dan Buddha melakukan ibadah, kebaktian dan hari raya melalui platform online.

Terlepas dari kesulitan-kesulitan yang dihadapi, ternyata terdapat banyak hikmah yang didapat oleh masyarakat. Banyak dari mereka yang terdampak jadi memiliki waktu kumpul bersama keluarga, kreativitas- 
kreativitas baru banyak muncul, peningkatan diri secara spiritual (khusyuk dan banyak beribadah), serta terpupuknya jiwa saling bantu (toleransi).

\section{DAFTAR PUSTAKA}

\section{Buku}

Prasojo, Lantip Diat, \& Riyanto. (2011). Teknologi Informasi Pendidikan. Yogyakarta: Gava Media.

\section{Jurnal dan lainnya}

Budiyanti, Eka. (2020). Dampak Virus Corona terhadap Sektor Perdagangan dan Pariwisata Indonesia. Bidang Ekonomi dan Kebijakan Publik Info singkat Kajian Singkat terhadap Isu aktual dan Strategis. Retrieved from http://sdip.dpr.go.id/search/detail/category/Info\%20Singkat/id/1039

Burhanuddin, Chairul, \& Abdi, M. (2020). Krisis Ekonomi Global Dari Dampak Penyebaran Virus Corona (Covid-19). AkMen Jurnal Ilmiah, 17 (1), 9098. https://doi.org/10.37476/akmen.v17i1.866

CNBC Indonesia. (2020). Ingat! Begini Cara Penyebaran Virus Corona Covid-19 versi WHO. Retrieved from https://www.cnbcindonesia.com/tech/20200608095052-37163746/ingat-begini-cara-penyebaran-virus-corona-covid-19-versiwho

CNBC Indonesia. (2020). Top 4 Saham Farmasi Cuan Terus, Ada yang Hampir 100\% Nih. Retrieved from https://www.cnbcindonesia.com/market/20200331100706-17148664/top-4-saham-farmasi-cuan-terus-ada-yang-hampir-10o-nih

Firman, \& Rahayu, Sari. (2020). Pembelajaran Online di Tengah Pandemi Covid-19, Indonesian. IJES: Journal of Educational Science, 2 (2), 8189. https://doi.org/10.31605/ijes.v2i2.659

Gugus Tugas Percepatan Penanganan Covid-19, Retrieved from https://covid19.go.id/

Hanoatubun, S. (2020). Dampak Covid - 19 terhadap Prekonomian Indonesia. EduPsyCouns: Journal of Education, Psychology and Counseling, 2(1), 146-153. Retrieved from https://ummaspul.ejournal.id/Edupsycouns/article/view/423

Hasbiyallah., dkk. (2020). Fikih Corona (Studi Pandangan Ulama Indonesia terhadap Ibadah dalam Kondisi Dharurat Covid-19). Retrieved from http://digilib.uinsgd.ac.id/30568/

Liputan 6. Virus Corona Covid-19 Bikin Kegiatan Keagamaan di Dunia Beradaptasi. Retrieved from https://www.liputan6.com/global/read/4209505/virus-corona-covid19-bikin-kegiatan-keagamaan-di-dunia-beradaptasi.

National Committee for Islamic Economy and Finance (KNEKS). (2020). Impacts of the Covid-19 Outbreak on Islamic Finance in the OIC Countries. 
Pakpahan, Aknolt Kristian. (2020). Covid-19 dan Implikasi Bagi Usaha Mikro, Kecil, dan Menengah. JIHI: Jurnal Ilmiah Hubungan Internasional, Edisi Khusus. https://doi.org/10.26593/jihi.voio.3870.59-64

Pujilestari, Yulita. (2020). Dampak Positif Pembelajaran Online Dalam Sistem Pendidikan Indonesia Pasca Pandemi Covid-19. ADALAH: Buletin Hukum dan Keadilan, 4 (1), 49-56. DOI: 10.15408/adalah.v4i1.15394

Purwanto, A., Pramono, R., Asbari, M., Hyun, C., Wijayanti, L., Putri, R., \& santoso, priyono. (2020). Studi Eksploratif Dampak Pandemi Covid-19 Terhadap Proses Pembelajaran Online di Sekolah Dasar. EduPsyCouns: Journal of Education, Psychology and Counseling, 2(1), 1-12. Retrieved from https://ummaspul.e-journal.id/Edupsycouns/article/view/397

Rahman, R. (2020). 37.000 SMEs Hit by Covid-19 Crisis as Government Prepares Aid. The Jakarta Post, 16 April 2020. Retrieved from https://www.thejakartapost.com/news/2020/o4/16/370oo-smes-hitby-covid-19-crisis-as-government-prepares-aid.html

Shofiana, Amalia. Implementasi Program Afiliasi Berbasis Virtual Team Dalam UMKM Sebagai Upaya Peningkatan Perekonomian Pada Masa Pandemi Covid-19. Fakultas Ekonomi dan Bisnis, Universitas Padjadjaran. Retrieved from https://www.readcube.com/articles/10.2139\%2Fssrn.3590822

Siregar, Hariman Surya., dkk. (2020). Merekonstruksi Alam dalam Kajian Sains dan Agama Studi Kasus pada Masa Pembatasan Sosial Berskala Besar (PSBB) Dampak Covid-19. $\quad$ Retrieved from http://digilib.uinsgd.ac.id/30700

Suherdiana, Dadan., dkk. (2020). Pesan Dakwah Ormas Islam Indonesia dalam Menghadapi Krisis Keagamaan Masa Pandemi Covid-19. Retrieved from http://digilib.uinsgd.ac.id/30775

Syatar, Abdul., dkk. (2020). Darurat Moderasi Beragama Di Tengah Pandemi Corona Virus Desease 2019 (Covid-19). KURIOSITAS: Media Komunikasi Sosial Dan Keagamaan, $13 \quad$ (1), 1-13. https://doi.org/10.35905/kur.v13i1.1376

Taufik., \& Ayuningtyas, Eka Avianti. (2020). Dampak Pandemi Covid-19 Terhadap Bisnis dan Eksistensi Platform Online (The Impact of Covid-19 Pandemic on Business and Online Platform Existance). Jurnal Pengembangan Wiraswasta, $22 \quad$ (1), 21-32. http://dx.doi.org/10.33370/jpw.v22io1.389

Zapalska, A. and Rozik, D. (2006). Learning Styles and Online Education). Camps-Wide Informatin Systems, 23 (5), p.325-335. 